\title{
OUTSOURCING V RIADENÍ L'UDSKÝCH ZDROJOV - ÁNO ČI NIE?
}

\author{
Mariana Strenitzerová ${ }^{1}$
}

\section{Úvod}

V poslednej dobe môžeme voblasti l'udských zdrojov pozorovat' výrazné skvalitňovanie tradičných služieb, ako sú poradenstvo a tréning interpersonálnych schopností, ale taktiež zvýšenie kvality poskytovania školiacich aktivít. Nemôžeme prehliadnut' rozvoj nových moderných a personalistami zatial' nie príliš využívaných služieb. Jednou z nich je aj outsourcing - teda využitie externej firmy k zaisteniu vybraných činností, ktoré si doteraz firma robila sama. Ten sa začína konečne stávat' bežnou súčastou personálnej práce. Spoločnosti sa v stále väčšej miere snažia sústredit' na core business - podstatné či hlavné smery svojho podnikania. „Podporné“ činnosti postupne prevádzajú na iné špecializované organizácie. Napr. spracovanie miezd, administratíva personálnej agendy, nábor a výber zamestnancov, často krát kvalitnejšie zaist’ujú externí dodávatelia.

\section{Vymedzenie pojmu a podstaty outsourcingu}

Slovo outsourcing je pomerne novým pojmom, ktorý sa v USA objavil v 70. rokoch 20. storočia. Toto $\mathrm{z}$ angličtiny prevzaté slovo vzniklo spojením anglických slov OUTside reSOURCe usING, čo vo vol’nom preklade znamená využívanie vonkajších zdrojov.

V literatúre sa môžeme stretnút' s viacerými definíciami outsourcingu. Väčšina autorov charakterizuje outsourcing ako využivanie služieb špecializovanej firmy na vykonávanie rutinných okrajových podnikových záležitostí, čím umožňuje plnú koncentráciu na klúčové záležitosti.

Z iného pohl'adu môžeme outsourcing charakterizovat' ako dohodu uzatvorenú medzi podnikom a tret’ou stranou pre nepretržité riadenie a zlepšenie aktivit súvisiacich s podnikom alebo jeho častou:

- podnikové funkcie (napr. l’udské zdroje, marketing, účtovníctvo),

- infraštruktúra (napr. informačné systémy, bezpečnostné systémy, telekomunikačné siete),

- prevádzkové funkcie (napr. zabezpečenie surovín, priemyselná výroba, činnost' telekomunikačných sietí).

Právnická definícia chápe outsourcing ako právny vzt’ah medzi dvomi alebo viacerými spoločnost’ami, z ktorých jedna vyčlení vlastníctvo, manažment a personál určitej činnosti do rúk špecializovanej firmy. Inými slovami outsourcing je vyčlenenie podnikového „,non-core“ alebo neziskových aktivít špecialistom.

\footnotetext{
${ }^{1}$ Ing. Mariana Strenitzerová, PhD., Žilinská Univerzita v Žiline, Fakulta prevádzky a ekonomiky dopravy a spojov, Katedra spojov, Univerzitná 1, 01026 Žilina, Slovenská republika

tel. 00421-041-5133 131, fax 00421-041-5655 615, e-mail: Mariana.Strenitzerova@fpedas.uniza.sk
} 
Outsourcing je proces transferu niektorých opakujúcich sa podnikových interných činností a rozhodovacích práv na externých poskytovatel'ov, podl'a vopred stanovenej zmluvy.

Všetky zo spomínaných definícií zdôrazňujú rozdiely v tom ako, kedy a kde je služba poskytovaná, t.j. interne verzus externe, v súčasnosti alebo $v$ minulosti, alebo či sa outsourcujú hlavné prípadne vedlajšie podporné funkcie.

\section{Vývoj outsourcingu v riadení l’udských zdrojov}

Human Resources Business Process Outsourcing (HR BPO) má svoj pôvod v 70. rokoch 20. storočia, kedy spoločnosti začali externe zadávat' jednoduché transakčné úlohy, ako napr. spracovanie miezd či spracovanie zamestnaneckých výhod.

V roku 1999 sa však zaznamenal raketový nástup toho, čo experti nazývajú „full spectrum outsourcing“ (celé spektrum outsourcovania činností), čo znamená presun transakčných prvkov hlavných procesov riadenia l'udských zdrojov k outsourcerovi súčasne. Znamená to tiež, že spoločnost' dáva oursourcerovi do rúk kontrolu nad spojením akýchkol'vek činností riadenia l'udských zdrojov, zahŕňajúc benefity, zdravie a sociálny prospech, riadenie výkonu, hodnotenie a odmeňovanie, odchody do dôchodku, technológiu a pod. HR BPO je momentálne najrýchlejšie rozvíjajúci sa segment z celého trhu BPO.

HR BPO zahŕňa radikálnu prestavbu dodávania služieb na úrovni podniku. Jeho hlavnou výhodou je, že pomáha spoločnostiam zbavovat' sa všetkej transakčnej, opakujúcej sa, i ked' dôležitej činnosti, ktorej pridaná hodnota je však vel'mi nízka a umožňuje sústredit' sa na 5 najpodstatnejších elementov: vyhl'adávanie, získavanie, vzdelávanie, odmeňovanie a rozvoj l'udského kapitálu.

Outsourcing činností riadenia l'udských zdrojov sa stáva podla mnohých pozorovatel'ov kl'účovým trendom, ktorý už dnes určuje budúcnost' manažmentu v oblasti riadenia l'udských zdrojov. Budúcnost'ou sú oddelenia riadenia l'udských zdrojov, ktoré sa budú sústredit' iba na strategické činnosti, z interného prostredia využívajúc možno len firemných konzultantov, tvorcov systému riadenia l'udských zdrojov a vrcholových predstavitel'ov riadenia l'udských zdrojov, prenechávajúc všetku administratívnu a transakčnú činnost' poskytovatel'om, pre ktorých sú práve tieto činnosti ústrednými.

Podstata outsourcingu riadenia l’udských zdrojov spočíva v tom, že firma nemá vlastné oddelenia alebo pracovníkov, ktorí sa starajú o jednotlivé aktivity v personálnej sfére, ale že si na tieto činnosti najíma personálne poradenské firmy. Poradenské firmy ponúkajú služby, ktoré sa týkajú personálneho manažmentu, a ktorých podoba vychádza predovšetkým z konkrétnych predstáv a potrieb jednotlivých firiem. Ide o organizáciu práce, výber l’udí, ich vzdelávanie, o personálne analýzy, manažérske audity, vypracúvanie personálnych stratégií, personálny lízing, poradenstvo pri prepúšt’aní pracovníkov (outplacement) a mnoho d'alších služieb.

Prínos kvalitného outsourcingu l'udských zdrojov ilustruje obr. 1. Personálny útvar podniku obyčajne rieši celý rad problémov, ktoré súvisia $\mathrm{s}$ bezprostredným dopadom na firmu. Dlhodobé problémy sú často odsúvané. Ako je zrejmé z obrázku (l’avá čast' obrázku), manažment firiem sa venuje len z $10 \%$ tomu, čo firmu ,živí “ a z $90 \%$ operatívnemu riadeniu. Pokial' sa však podarí operatívne problémy preniest' na externý subjekt, s najväčšou pravdepodobnost'ou sa situácia obráti (pravá čast' obrázku). Za tejto novej situácie personálne oddelenie skutočne riadi l'udské zdroje (s dlhodobou perspektívou) a je partnerom manažmentu. 
Outsourcing pomáha vyriešit' i d’alšie situácie:

- ked' si spoločnosti nemôžu dovolit' zaplatit' kvalitných personálnych odborníkov outsourcingom ich nakúpia ako službu,

- outsourcer sa stará o vývoj a rozvoj podporných činností, nemusí sa o ne starat' firma,

- rovnako tak prechádza na outsourcera i povinnost' starat'sa o nové technológie,

- interné riadenie l'udských zdrojov by neúmerne zvýšilo nákladové položky.

Obr. 1. Prínos outsourcingu l’udských zdrojov
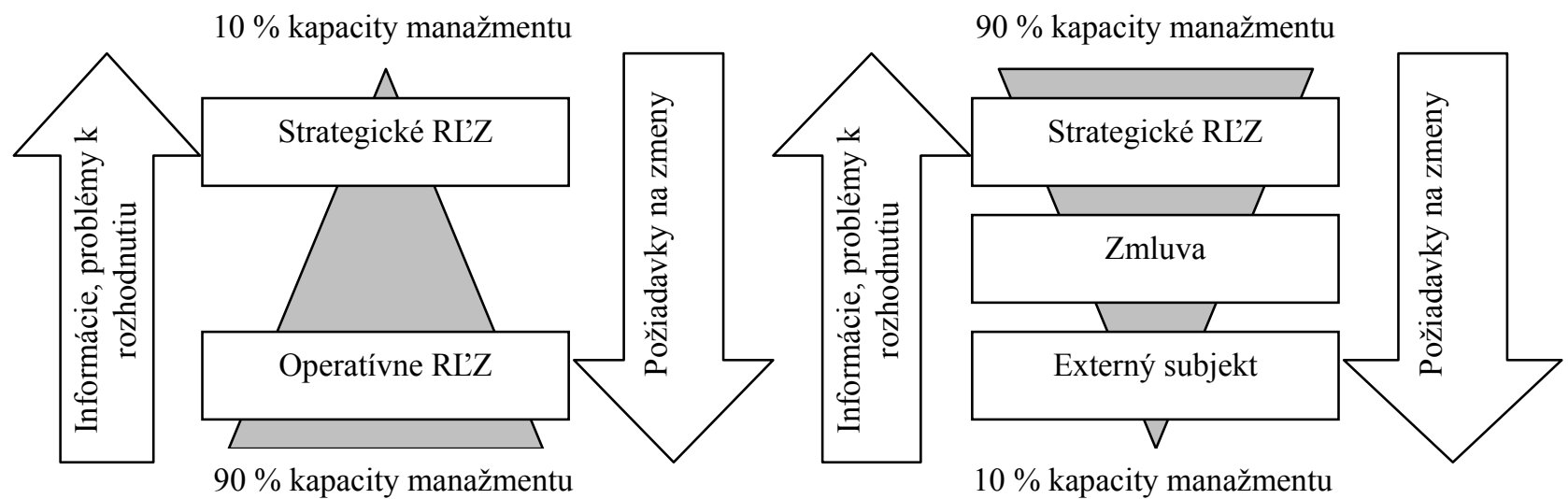

Outsourcing činností riadenia l'udských zdrojov vo všeobecnosti umožňuje manažérom prehodnotit' výhody a nevýhody outsourcingu, zároveň pomáha interpretovat' manažérske otázky z pohl'adu príležitostí a komplexnosti outsourcingu ako takého. Medzi najčastejšie outsourcované funkcie $v$ tejto oblasti patria:

- spracovanie mzdovej agendy: v súčasnosti čoraz väčší počet firiem profituje z outsourcingu spracovania miezd (Payroll Process Outsourcing). Outsourcingové spoločnosti ponúkajú tieto služby: prevzatie a analýza mzdových údajov, vykazovanie a odvody daní z príjmov, riadenie príkazov na úhradu a vystavovanie potvrdeniek pre zamestnancov, uskutočňovanie platieb tretím stranám a pod.

- personálne vyhl'adávanie a výber: spoločnosti dnes rady presúvajú náborové aktivity pod správu špecialistov, ktorí vel'mi dobre poznajú trh práce, majú cit pre talent a vedia zladit' potreby spoločnosti s l'ud'mi, ktorých potrebuje. Špecialistom na riedenie l'udských zdrojov tak šetria čas a energiu na strategické aktivity. Personálno-poradenské subjekty sú špecializované na vyhl'adávanie, výber a hodnotenie l'udského kapitálu. Svojim klientom poskytujú služby, resp. poradenské riešenia. Hlavným predmetom ich činnosti je poradenstvo podnikom v oblasti riadenia l'udských zdrojov. Uvedené subjekty sa delia na:

o personálno-poradenské agentúry (Recruitment\&Selection), ktoré sa špecializujú na vyhl'adávanie vhodných kandidátov na nižšie a stredné pozície. Pri vyhl'adávaní pracujú väčšinou s internými a externými databázami a svojich kandidátov získavajú predovšetkým zviditel'nením ponuky na trhu. Ide o tzv. advertising selection,

o tzv. executive search predstavuje priame vyhl'adávanie pracovníkov. Ide najmä o cielené vyhl'adávanie a obsadzovanie top manažérskych a vysoko špecializovaných pracovných pozícií, realizovaných na základe špecificky stanovených konkrétnych podmienok a potrieb klienta. 
- zamestnanecké výhody: zamestnanecké výhody a benefity boli a budú jedným z hlavných problémov personalistiky. Mnoho podnikov dnes začína ovel'a intenzívnejšie kontrolovat' výdavky v tejto oblasti. Personalisti hl'adajú stále nové možnosti ako ušetrit', zúčastňujú sa na rokovaniach s predajcami a komunikujú o zmenách so zamestnancami. Outsourcingové spoločnosti im túto prácu ul'ahčujú - ponúkajú služby rôzneho typu:

o prerozdel'ovanie a distribúcia plánov zdravotnej starostlivosti a odchodov do dôchodku,

o riadenie spôsobilosti, oprávnenosti dostat' zamestnanecký benefit,

o zodpovedanie otázok týkajúcich sa pol'a pôsobnosti,

o sledovanie priebehu dovoleniek a dní vol'na,

o udržiavanie a podpora procesu vyplácania dôchodkov, odhadovanie odchodov do dôchodku a ukončenie administrácie zamestnaneckých výhod.

- personálny lízing: pod pojmom personálny lízing sa rozumie personálna služba zameraná na zabezpečenie komplexnej administratívy a správy spojenej so vznikom, priebehom a skončením pracovného pomeru zamestnancov dočasne vykonávajúcich prácu u zadávatel'a. Dočasné pridelenie zamestnancov umožňuje vel'mi flexibilne menit' počet prijatých zamestnancov podl'a momentálnych potrieb podniku. Personálna agentúra zamestnanca vyhl'adá, príjme ho do pracovného pomeru a prevezme zaňho kompletnú personálnu a mzdovú agendu. Personálny lízing je založený na zmluvnom vzt’ahu personálnej agentúry so zadávatel'ským podnikom na jednej strane a so zamestnancom na strane druhej, pričom zadávatel'ský podnik nevstupuje do pracovno-právneho vzt’ahu so zamestnancom. Personálny lízing sa vyznačuje týmito charakteristikami:

o flexibilní zamestnanci, pripravení začat' a skončit's prácou kedykol'vek,

o podnik nemá starosti so získavaním kmeňových zamestnancov,

o žiadna mzdová administratíva, žiadne pracovné zmluvy podniku so zamestnancom,

o zredukovanie počtu fixných zamestnancov.

- tréningové a vzdelávacie programy: tieto programy majú zvyčajne formu individuálnych konzultácií orientovaných na konkrétneho človeka alebo formu skupinovej práce v rámci programu komplexného rozvoja osobnosti. Spoločnosti, ktoré sa špecializujú na túto oblast', ponúkajú školenia, ktoré sú prispôsobené skupine a obohatené o nácvik rôznych komunikačných techník a prístupov $\mathrm{v}$ rámci pestrejšieho sociálneho pol'a, pripravujú náročnejšie tréningové programy a pod.

- assesment center: metóda hodnotiaceho centra poskytuje dobrú príležitost' na posúdenie toho, do akej miery uchádzači vyhovujú kultúre organizácie. Súčast'ou tejto metódy je pozorovanie správania sa uchádzačov v rôznych typických situáciách, testy a tiež štruktúrované pohovory.

- personálny kaučing: je jedna z najnovších foriem poradenstva. Patrí k metódam priamej podpory, systematického rozvoja a dlhodobého vzdelávania manažérov. Pomáha pri riešení konkrétnych riadiacich úloh a rozhodnutí, ktoré nie sú bežnou súčast'ou manažérskej práce.

- outplacement: outplacement predstavuje pomoc nadbytočným pracovníkom pri hl'adaní náhradného zamestnania. Zahŕňa i pomoc poskytovanú jedincom, aby sa prostredníctvom rôznych konzultácií vyrovnali s duševným otrasom spôsobeným prepustením, pomoc súvisiacu so zmenou kariéry a pracovných ciel'ov v podobe inteligentných, ale citlivých pokynov, ako tieto ciele dosiahnut'. Výhody plynúce z využitia outplacementových služieb sú pre podnik a jeho zamestnancov nasledovné: 
o spoločnost' má kontrolu nad celým procesom reorganizácie,

o zachováva si pozitívny imidž,

o udržuje produktivitu práce a morálku zostávajúcich zamestnancov,

o nadbytoční zamestnanci získajú psychologickú podporu vokamihu straty zamestnania,

o zamestnancom je poskytnuté profesionálne poradenstvo skúsenými konzultantmi v oblasti riadenia kariéry,

o zvýši sa ich šanca na d'alšie uplatnenie na trhu práce a pripravia sa na aktívne hl'adanie nového zamestnanca.

\section{Výhody a nevýhody outsourcingu}

Outsourcing funkcií riadenia l’udských zdrojov má niekol'ko výhod:

- odbremeňuje riadiacich pracovníkov od transakčných a administratívnych úloh, takže sa môžu sústredit' na strategické úlohy a podnik môže využívat' decentralizované štruktúry, ktoré budú podporovat' vyšší stupeň inovácie a flexibility,

- umožňuje útvaru riadenia l'udských zdrojov zohrávat' svoju úlohu v celkovom podnikovom procese downsizingu a vytvárat' lepší prístup k novým myšlienkam zvonku organizácie.

$\mathrm{Na}$ druhej strane však existujú aj v tom prípade určité prekážky a riziká, ako napr.: vyššie náklady, nižšia kvalita či strata kontroly.

Všetky tieto „pre a proti“ sa môžu prejavovat' rozdielne, a to jednak vzhl'adom na vel'kost' firmy alebo vzhl'adom na variabilitu procesov riadenia l'udských zdrojov. Vo všeobecnosti platí, že dopyt po rozsiahlych integrovaných systémoch služieb riadenia l'udských zdrojov je najmä zo strany vel'kých korporácií, malé firmy outsourcujú väčšinou len spracovanie miezd.

Tabul'ka 1 ponúka prehl'ad hlavných výhod a nevýhod outsourcingu. Za nepochybne významný pozitívny faktor považujú viaceré spoločnosti znižovanie nákladov. Uvážený outsourcing sa však môže postarat' o d'alšie dlhodobé úžitky, napr.:

- šetrenie na administratívnych nákladoch pri činnostiach, ktoré si síce vyžadujú odbornost', ale spoločnost' túto odbornost' obvykle využíva len zriedka, alebo predstavuje problém len v prípade zvýšeného stupňa zat'aženia,

- outsourcing býva uprednostňovaný tiež v činnostiach, ktoré sú považované za menejcenné

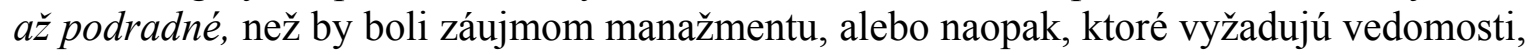
ktoré manažmentu chýbajú,

- jeden z častých administratívnych dôvodov býva únik od problémov spojených s právnou zodpovednostou za zamestnancov. S čím úzko súvisí napr. zdravotné poistenie a sociálna bezpečnost' zamestnancov, aspekt súkromia zamestnancov, platenie daní, diskriminácia pri prijímaní do zamestnania, pracovnom postupe, prepúšt’aní alebo len pri obyčajnom každodennom zaobchádzaní s pracovníkmi. 
Tab. 1. Hlavné vývody a nevýhody outsourcingu

\begin{tabular}{|c|c|}
\hline & \\
\hline $\begin{array}{l}\text { - } \text { zaistenie a udržanie konkurencieschopnosti } \\
\text { - } \quad \text { zvýšenie ekonomickej výkonnosti } \\
\text { - } \text { koncentrácia zdrojov na hlavné predmety } \\
\text { - } \text { zodnikania firmy } \\
\text { - } \text { zrocensenie zdrojov na zlepšenie dôležitých business } \\
\text { - } \text { zvýšenie návratnosti investícií do IT } \\
\text { - a zvýšenie výnosov } \\
\text { - zjednodušenie manažérskej práce } \\
\text { - zjednodušenie (sploštenie) organizačnej štruktúry } \\
\text { - firmy - stratégia „,lean managementu“ } \\
\text { - flexibilnejší ako zadávajúca firma } \\
\text { - jediel'anie rizika s poskytovatelom služieb } \\
\text { - odkrytie skutočných nákladov na aktivitu dodávanú } \\
\text { - externe } \\
\text { dosiahnutie vyššej kvality poskytovaných služieb } \\
\text { v porovnaní s činnostou vykonávanou vlastnými }\end{array}$ & $\begin{array}{l}\text { - } \quad \text { závislost' na poskytovatel’ovi } \\
\text { - } \quad \text { rizžieb } \\
\text { - } \quad \text { vplyv okolitého prostredia na } \\
\text { podmienky spolupráce } \\
\text { s poskytovatel'om služieb } \\
\text { - } \quad \text { riziko vyplývajúce z nevýhodne } \\
\text { postavenej zmluvy o dodávke } \\
\text { služieb } \\
\text { - nesplnenie pôvodných } \\
\text { očakávaní v oblasti zníženia } \\
\text { nákladov (zákazník nesprávne } \\
\text { odhadne všetky pôvodné } \\
\text { interné náklady) } \\
\text { - z pohl'adu poskytovatel'a } \\
\text { spravidla nutná vel'mi dobrá } \\
\text { znalost' klienta, príp. jeho } \\
\text { strategických ciel'ov a plánov } \\
\text { zákazník vel'akrát kupuje alebo } \\
\text { objednáva službu, ktorej } \\
\text { kvalitu nepozná }\end{array}$ \\
\hline
\end{tabular}

Vd'aka outsourcingu si dnes firmy dokážu sprostredkovat' svoje okamžité potreby ovel'a rýchlejšie. Personálna agentúra vie obsadit' pozície výrazne rýchlejšie ako zamestnávatel' a často spôsobilejšie vybrat' jednotlivcov s lepšou kvalifikáciou, prípadne použit' vlastný etablovaný tím schopných odborných pracovníkov. Z toho môžu t'ažit' hlavne menšie podniky, v prípade že majú nedostatok skúseností ako pritiahnut', vybrat' alebo zaškolit' pracovníkov.

Vel'akrát sa však stretávame aj sproblémami a nevýhodami spojenými s outsourcingom. V outsourcingových projektoch bývajú v hre značné finančné čiastky. Navyše takýto krok môže mat' významný vplyv na trhovú hodnotu celej firmy. Treba mat' preto vždy na pamäti skutočnost', že projekt, ktorý nie je správne riadený, môže spoločnost' oslabit'. V každom prípade bude pre spoločnost' dôležité, aby sa tak nedialo v rozpore so strategickými záujmami. Manažéri si musia byt' preto pred každým takýmto strategickým rozhodnutím vedomí aj možných problémov a negatívnych stránok spojených s využívaním outsourcingu, ako napr.:

- náklady spojené s koordináciou: t’ažkosti môžu nastat' hlavne pri zosúladení produkcie s externými poskytovatel'mi, čomu sa dá pri kontrole „doma“ vyhnút',

- kvalita a problémy s poskytovaním služieb: vo všeobecnosti je tendencia spoliehat' sa na kvalitu, ale kvalita sa, na druhej strane, t’ažko preveruje,

- náklady transakcie: ide o náklady spojené s hl’adaním a výberom dodávatel'a,

- náklady monitorovania: podniky ich vynakladajú najmä v záujme zníženia možnosti, že sa zamestnanci budú ulievat', pretože to by mohlo mat' za následok zníženie kvality poskytovaných služieb, 
- kontrola: outsourcing môže spôsobit' stratu kontroly nad kl'účovými oblast’ami, nevynímajúc zamestnanecké vzt’ahy a manažovanie zamestnancov.

Častými príčinami neuspokojivých výsledkov outsourcingu sú nároky kladené na l’udí zainteresovaných $\mathrm{v}$ rozhodovacom procese. Ak sa firma rozhodne outsourcovat' svoje aktivity, manažéri by mali uvažovat' s budúcou strategickou pozíciou firmy, jej zdrojmi a kapacitami. Výsledky nemusia byt' uspokojivé, ak dôjde k rozhodnutiu len na základe posúdenia a vyčíslenia nákladov. Aj ked' kvantifikovatel'né analýzy nákladov hovoria v prospech outsourcingu, môžu nastat' aj mnohé nepredvídatel'né okolnosti, ktoré zapríčiňujú d'alšie priame a nepriame náklady, ktoré môžu prevážit' and výhodami.

\section{Dopad outsourcingu na l'udské zdroje a jeho vplyv na vzt'ahy v podniku}

Outsourcing je vo vel'kej miere o l'ud'och. A skúsenost' ukazuje jasne - na l'ud'och záleží. Bezpečnost', nevypovedané pocity pracovníkov počas transferu, dopad na zvyšok tímu, reputácia, nedorozumenia, strata dôvery, motivácie či angažovanosti v prospech podniku - to všetko môže, ale aj nemusí byt' outsourcing. Môže trvat' aj niekol'ko rokov, kým sa negatívne následky niekde prejavia.

Väčšina literatúry o riadení l’udských zdrojov zdôrazňuje, že na to, aby bola firma konkurencieschopná, potrebuje prijat' stratégie, ktoré pomôžu vybudovat' oddanost' zamestnancov. Je však možné, že outsourcing si vyžiada využitie najmä externých zamestnancov po boku riadnych zamestnancov, a práve to môže spôsobovat' problémy s odovzdaní sa zamestnancov podniku. Aby sa vzt'ah medzi firmou a jej vlastnými zamestnancami vyvíjal pozitívne, je vel'mi dôležité, aby boli tieto vzt'ahy konštruktívne a postavené na flexibilnom a dlhodobom základe. Outsourcing totiž môže spôsobit' voči firmám určitý druh dvojitého záväzku: oddanost' zamestnancov voči podniku, kde pracujú rovnako ako voči firme, ktorá ich sprostredkováva (personálna agentúra).

Prítomnost' dodávatel'ov je spojená s nižšiu dôverou medzi rádovými zamestnancami firmy, pretože tí vnímajú dodávatel’a ako hrozbu ich vlastnej pozície, čo vedie k rozvráteniu vzt'ahov medzi zamestnancami. Negatívne pre obe strany sa môže prejavit' tiež nerovnost' v podmienkach a peňažnom ohodnotení, čo môže spôsobit' nátlak a stres a podlomit' kolektívneho ducha a tímovú prácu oboch skupín.

Byt' zamestnancom znamená určitý sociálny status. Je evidentné, že kmeňoví zamestnanci vykazujú ovel'a viac lojality a hlbši záujem voči spolupracovníkom a spoločnosti ako takej ako dočasní zamestnanci. Toto je do značnej miery ovplyvnené podnikovou kultúrou. Požičaní zamestnanci vedia, že ich pracovné miesto je dočasné, sú menej motivovaní podávat' výkony, navyše zamestnávatel' nepočíta s ich začlenením do sociálnych funkcií alebo motivačných programov, čím sa u nich vytvára pocit vylúčenia, čo vyúst'uje k slabšej morálke hned’ ako vycítia, že sa s nimi nezaobchádza rovnocenne.

Iný negatívny dôsledok outsourcingu je dopad na schopnosti a tréning. Vo všeobecnosti platí, že vlastní zamestnanci podniku predstavujú lepší l'udský kapitál pre podnikové „core“ kompetencie (rozhodujúce kl’účové schopnosti, ktoré podnik nevyhnutne potrebuje). Ked’že sa očakáva, že v podniku budú pracovat' dlhšie obdobie, stávajú sa títo zamestnanci viac flexibilnými, čo je dôležité hlavne v úlohách, ktoré si vyžadujú dobré pracovné vzt'ahy a tiež v dlhodobých úlohách, kde môže trvat' roky, kým sa dostavia požadované výsledky. A pretože požičaní pracovníci vykazujú len málo vernosti hostitel'skej firme, často nie sú ochotní spolupracovat's rádovými zamestnancami na zlepšovaní procesov a zvyšovaní produktivity práce. 
Zmluvné záväzky sú dôležité najmä pre podniky, ktorých stratégie sú založené na nepretržitom zlepšovaní produktov a služieb, alebo ktoré vyžadujú transfer vedomostí a know-how získaného v určitom produkte, službe alebo divízii k iným častiam. Takéto firmy môžu utrpiet' značné škody $\mathrm{v}$ prípade, že bol outsourcing urobený neuvážene a bez zohl'adnenia rozdielov.

Čo sa týka administratívneho hl'adiska, na rozdiel od relatívne nákladného náboru, d’alšieho vzdelávania a kompenzovania spojeného so zamestnávaním vlastných zamestnancov, zamestnanci nezávislého dodávatel'a nepredstavujú žiadne priame náklady pre podnik. Aj ked' podnik musí platit' poplatok firme, ktorá poskytuje dočasných pracovníkov. Týmto spôsobom jej pokrýva náklady súvisiace s najímaním a riadením vlastného personálu, plus zahŕňa aj určitý zisk. Prenajat' si pracovníkov prostredníctvom dodávatel'a pracovnej sily nedokáže eliminovat' náklady úplne, ale ide o to, že nezávislý dodávatel' dokáže realizovat' všetky administratívne problémy súvisiace s pracovníkmi ovel’a efektívnejšie.

Kritici outsourcingu stále poukazujú na to, aby sa úspory nákladov dôkladne prehodnotili oproti d'alším ovel'a vyšším nákladom a dlhodobým negatívnym dôsledkom.

\section{Záver}

I ked' outsourcing, ako vyplýva z príspevku, má mnoho „pre“ aj „proti“, nie je už len módnym pojmom, ale stal sa svetovým trendom, ktorý ponúka riešenie praktických problémov dnešných firiem.

\section{Literatúra}

[1] STÝBLO, J.: Outsoourcing a outplacement, ASPI, a.s., Praha, ISBN 80-7357-094-7

[2] CHLEBÍKOVÁ, D.: Outsourcingové riešenia $\mathrm{v}$ podnikovej praxi: kedy a prečo? Podniková ekonomika a Manažment [elektronický zdroj] : elektronický odborný časopis o ekonomike, manažmente, marketingu a logistike podniku. - ISSN 1336-5878. - Roč. 2 , č. 3 (2006), s. 60-64.

[3] VACULÍK, J., KRUPPA, M.: Obchodný model novej ekonomiky, Logistika : měsičník Hospodářských novin. - ISSN 1211-0957. - Roč. 12, č. 2 (2006), s. 32-33.

[4] WALKER, A. J. a kol.: Moderní personální management. Nejnovější trendy a technologie. Praha, Grada Publishing a.s., 2003, ISBN 80-247-0449-8

\section{Grantová podpora}

Príspevok vznikol na základe riešenia projektu 1/4573/07 Možnosti, ohraničenia a vývojové tendencie koncepcie univerzálnej služby v pošte a telekomunikáciách v procese globalizácie. 